\title{
We Take Care of Person with Obesity, Not Obesity That People Has
}

\author{
Sang Yeoup Lee* \\ Family Medicine Clinic and Research Institute of Convergence of Biomedical Science and Technology, Pusan \\ National University Yangsan Hospital, Yangsan; Department of Medical Education, Pusan National \\ University School of Medicine, Yangsan, Korea
}

\author{
Received April 6, 2019 \\ Reviewed April 26, 2019 \\ Accepted May 13, 2019 \\ ${ }^{*}$ Corresponding author \\ Sang Yeoup Lee \\ https://orcid.org/0000-0002-3585-9910 \\ Department of Medical Education, \\ Pusan National University School of \\ Medicine, 49 Busandaehak-ro, \\ Mulgeum-eup, Yangsan 50612, Korea \\ Tel: $+82-51-510-8024$ \\ Fax: +82-51-510-8125 \\ E-mail: saylee@pnu.edu
}

In Roman Holiday, the film which was released in 1953, Gregory Peck, who plays Joe, tells Audrey Hepburn, who plays princess Anne, "Life is not always what one likes." That's right. Things don't always go as we wish. Not all obese people succeed in losing weight. There are many cases where weight loss cannot be achieved even with all kinds of efforts ${ }^{1}$, because obesity is a chronic disease that needs lifelong care like hypertension and diabetes mellitus. People do not blame patients with hypertension or diabetes mellitus, while often blame obese people when they do not lose weight properly. ${ }^{2}$ People regard being obese as their fault. Doctors, colleagues, bosses in the workplace, and even families criticize those who cannot control their weight. ${ }^{3}$ Many people still have prejudices against obese people such as that obese people would be lazy, weak, intellectually inadequate, have no plan, or do not control or manage themselves properly. ${ }^{4}$ Obesity itself stigmatizes them; it is called obesity stigma or weight stigma. Basically, branding begins with tagging. This leads to stereotyping, discrimination and loss of status, leading to discrimination against obese people. ${ }^{5}$

Unlike these stigmas, obese people are not like these misunderstandings. It's a completely wrong idea. Obesity results from a combination of various genetic, behavioral social and environmental factors. ${ }^{6}$ Obesity is a chronic disease. ${ }^{7}$ We do not stigmatize people with hypertension or diabetes mellitus. People do not humiliate or discriminate against them, ignore them or treat them rudely. The reason is that the perception of hypertension or diabetes mellitus is not what it used to be like in the past. Now they are perceived as healthy controllable diseases. Obesity is just another chronic disease like hypertension or diabetes mellitus. Nevertheless, we still look at obese people from a different perspective. As a result, people who are obese receive direct or indirect social discrimination. They suffer from irritability everywhere, such as language violence, denial of service, harassment, discrimination in employment, low perceived academic achievement, pay discrimination, and job discrimination. ${ }^{8}$ Imagine if your children had obesity, and they were unable to lift their head up as if they were sinners and people would blame or ridicule them with a gleeful look. This is a very serious problem. I feel that the media has contributed to worsening the obesity stigma. ${ }^{9}$

The mass media has been ridiculing obese people and has been caricaturing them. ${ }^{10}$ It is hard to find obese people play the main character, yet easy to find them play binge eating extras at a restaurant in the media. This way, they often become the targets of mockery. The stigma and stereotypes of obese people have been strengthened by the influence of the mass media. Even the programs that 
Table 1. Helpful resources

\begin{tabular}{|c|c|}
\hline Resource & URL \\
\hline \multicolumn{2}{|l|}{ Obesity Action Coalition } \\
\hline People-first language for obesity & $\begin{array}{l}\text { https://4617c1smqldcqsat27z78x17-wpengine.netdna-ssl.com/wp-content/uploads/People-First. } \\
\text { pdf }\end{array}$ \\
\hline Guidelines for media portrayals of individuals affected by obesity & $\begin{array}{l}\text { https://4617c1smqldcqsat27z78x17-wpengine.netdna-ssl.com/wp-content/uploads/Guidelines- } \\
\text { for-Media-Portrayals-of-Individuals-Affected-by-Obesity-2016.pdf }\end{array}$ \\
\hline \multicolumn{2}{|l|}{ Leeds Beckett University } \\
\hline Media guidelines: avoiding weight stigma \& discrimination & $\begin{array}{l}\text { http://student.leedsbeckett.ac.uk/carnegie-school-of-sport/-/media/files/schools/schoolofsport/ } \\
\text { wof_media_guidelinesdev1.pdf?la=en }\end{array}$ \\
\hline \multicolumn{2}{|r|}{ 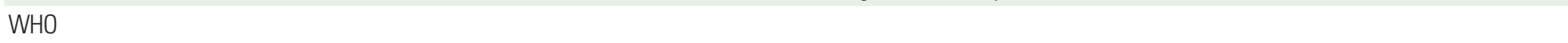 } \\
\hline Weight bias and obesity stigma: considerations for the WHO European region & http://www.euro.who.int/_data/assets/pdf_file/0017/351026/WeightBias.pdf \\
\hline \multicolumn{2}{|l|}{ Obesity Australia: understanding and action } \\
\hline Rethink obesity: a media guide on how to report on obesity & $\begin{array}{l}\text { https://static1.squarespace.com/static/57e9ebb16a4963ef7adfafdb/t/57ea17b0f7e0ab1a3449e } \\
\text { f1b/1474959285344/A-media-guide-on-how-to-report-on-obesity.pdf }\end{array}$ \\
\hline
\end{tabular}

WHO, World Health Organization.

intend to break down the obesity stigma result in reproducing obesity stigma. In programs for children and adolescent, as well as adult programs, obese people were often depicted as aggressive, antisocial, unattractive, and unkind., , $11^{11}$

The first record of obese people titled "The ideal husband is fatty person. You are blessed when you are fat. How to lose weight without harm" in Korean newspaper released on August 14, 1925, described obese Koreans as "fatty." ${ }^{2}$ Obese people at that time were already being called fat, and this implies that prejudice against obesity has been prevalent in Korea for a long time. On March 20, 2019, more than 90 years later, The Asia Business Daily still describes obese people as fatty people, as indicated in the newspaper entitled "He was originally fatty person." ${ }^{13}$ And when mass media use photos or pictures of obese people, they often choose portrayals that induce or reinforce obesity. Even if Article 11 of the Constitution of the Republic of Korea states "All citizens are equal before the law.”, obese people are still not treated equally.

Finally, I would like to make a suggestion. There are many other stigmatizing factors, but at least we need to improve from the media. Other international academic and social organizations have already prepared and are preparing guidelines to use the terms and pictures that express or refer to obese people. Some of them are shown in Table 1. In Korea, the Korean Society for the Study of Obesity has taken the initiative in eliminating obesity stigma, and now it seems to be the time to establish proper information of obesity, language guidelines, and image guidelines.

\section{CONFLICTS OF INTEREST}

The author declares no conflict of interest.

\section{REFERENCES}

1. Frühbeck G, Toplak H, Woodward E, Halford JC, Yumuk V; European Association for the Study of Obesity. Need for a paradigm shift in adult overweight and obesity management: an EASO position statement on a pressing public health, clinical and scientific challenge in Europe. Obes Facts 2014;7:408-16.

2. Puhl RM, Heuer CA. Obesity stigma: important considerations for public health. Am J Public Health 2010;100:1019-28.

3. Puhl RM, Heuer CA. The stigma of obesity: a review and update. Obesity (Silver Spring) 2009;17:941-64.

4. Brewis AA. Stigma and the perpetuation of obesity. Soc Sci Med 2014;118:152-8.

5. Brewis A, SturtzSreetharan C, Wutich A. Obesity stigma as a globalizing health challenge. Global Health 2018;14:20.

6. Dreher M, Hoffmann SW, Brendel C, Heser D, Simon P. Convenience behavior and being overweight in adults: development and validation of the convenience behavior questionnaire. Front Public Health 2019;7:20.

7. Bray GA, Kim KK, Wilding JP; World Obesity Federation. Obesity: a chronic relapsing progressive disease process. A position statement of the World Obesity Federation. Obes Rev 2017; 18:715-23. 
8. Flint SW, Snook J. Disability discrimination and obesity: the big questions? Curr Obes Rep 2015;4:504-9.

9. Kim MJ. Discrimination against obese women and their diet: centered on women in their 20-30s. Korean J Soc Issues 2016; 29:93-136.

10. Flint SW, Nobles J, Gately P, Sahota P; Association for the Study of Obesity; Obesity Empowerment Network, et al. Weight stigma and discrimination: a call to the media. Lancet Diabetes Endocrinol 2018;6:169-70.
11. Fruh SM, Nadglowski J, Hall HR, Davis SL, Crook ED, Zlomke K. Obesity stigma and bias. J Nurse Pract 2016;12:425-32.

12. Lee DJ. The ideal husband is fatty person. You are blessed when you are fat. How to lose weight without harm. The Dong-a Ilbo 1925 Aug 14.

13. Kim GY. Cultwo show 'Kwon Hyuck-Soo' 40 kg weight loss at once, was originally fatty [Internet]. Seoul: The Asia Business Daily; 2019 [cited 2019 May 13]. Available from: https:// www.asiae.co.kr/news/view.htm?idxno=2019032015250129570 